\title{
Microalga Scenedesmus obliquus: extraction of bioactive compounds and antioxidant activity ${ }^{1}$
}

\author{
Microalga Scenedesmus obliquus: extração de compostos bioativos e atividade \\ antioxidante
}

\author{
Monique Ellen Torres da Silva²*, Marcio Arêdes Martinss ${ }^{3}$, Maurício de Oliveira Leite ${ }^{3}$, Gustavo Leite Milião² \\ and Jane Sélia dos Reis Coimbra ${ }^{2 *}$
}

\begin{abstract}
Microalgae have been researched as a sustainable source of bioactive compounds for the food and pharmaceutical industries. The objectives of this work were the extraction and the characterization of fatty acids of Scenedesmus obliquus and to separate, quantify, and evaluate the antioxidant capacity of carotenoids and phenolic compounds of this microalga. The microalga cells were disrupted by using ultrasound. The centesimal composition of lyophilized cells was determined. Fatty acids of the oil were converted into methyl esters and analyzed by gas chromatography (flame ionization detector) to obtain the fatty acid profile. Acetone, petroleum ether, and hexane were the solvents applied to extract the carotenoids and ethanol was used to separate the phenolic compounds. The antioxidant activity of the extracts was determined by the DPPH method. The amount of polyunsaturated fatty acids corresponded to $47.31 \%$ of the total for unsaturated, with the predominance of linolenic acid (16.74\%) and approximately $9.70 \%$ of omega- 6 . The content of extracted carotenoids was

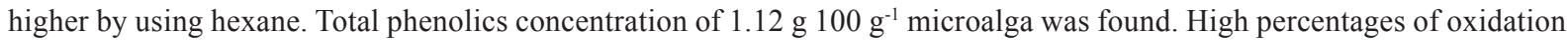
inhibition were observed for the extracts of carotenoids ( $>88 \%)$ and phenolic compounds ( $>72 \%)$. Therefore, Scenedesmus obliquus presents itself as an alternative, natural, and sustainable source of bioactive compounds.
\end{abstract}

Key words: Linolenic acid. Carotenoids. Phenolic compounds. Polyunsaturated fatty acid.

RESUMO - As microalgas têm sido pesquisadas como fonte sustentável de compostos bioativos para as indústrias alimentícia e farmacêutica. Os objetivos deste trabalho foram extrair, caracterizar ácidos graxos de Scenedesmus obliquus e separar, quantificar e avaliar a capacidade antioxidante de carotenóides e compostos fenólicos desta microalga. As células de microalga foram rompidas usando ultra-som. Determinou-se a composição centesimal das células liofilizadas. Os ácidos graxos do óleo foram convertidos em ésteres metílicos e analisados por cromatografia gasosa (detector de ionização de chama) para obtenção do perfil de ácidos graxos. Acetona, éter de petróleo e hexano foram os solventes aplicados para extrair os carotenóides e o etanol foi utilizado para separar os compostos fenólicos. A atividade antioxidante dos extratos foi determinada pelo método DPPH. A quantidade de ácidos graxos poliinsaturados correspondeu a 47,31\% do total para insaturados, com predomínio de ácido linolênico $(16,74 \%)$ e aproximadamente $9,70 \%$ de ômega-6. O teor de carotenóides extraídos foi maior usando hexano. Concentração fenólica total de $1,12 \mathrm{~g} \cdot 100 \mathrm{~g}^{-1}$ microalga foi encontrada. Altos percentuais de inibição da oxidação foram observados para os extratos de carotenóides (> 88\%) e compostos fenólicos (> 72\%). Portanto, Scenedesmus obliquus apresenta-se como uma fonte alternativa, natural e sustentável de compostos bioativos.

Palavras-chave: Ácido linolênico. Carotenóides. Compostos fenólicos. Ácido graxo poliinsaturado.

DOI: $10.5935 / 1806-6690.20210036$

Editor-in-Article: Professor Alek Sandro Dutra - alekdutra@ufc.br

*Author for correspondence

Received for publication 04/08/2019; approved on 20/10/2020

'Parte da Tese de doutorado da primeira autora, apresentada ao Programa de Pós-Graduação em Ciência e Tecnologia de Alimentos da Universidade Federal de Viçosa - PPGCTA/UFV

${ }^{2}$ Departamento de Tecnologia em Alimentos, Universidade Federal de Viçosa/UFV, Viçosa-MG, Brasil, moniqueellentorres0@gmail.com (ORCID ID 0000-0002-4540-475X), gustavoleitemiliao@gmail.com (ORCID ID 0000-0002-9511-7636), jcoimbra@ufv.br (ORCID ID 0000-0002-5998-189X) 3Departamento de Engenharia Agrícola, Universidade Federal de Viçosa/UFV, Viçosa-MG, Brasil, aredes@ufv.br (ORCID ID 0000-0001-5705-9431), mauricio.leite@ufv.br(ORCID ID 0000-0002-1666-2581) 


\section{INTRODUCTION}

Microalgae have been researched as an attractive source of bio-compounds for the biofuel, cosmetics, food, and pharmaceutical industries (SASSI et al., 2019; SATHASIVAM et al., 2019), such as lipids, proteins, carbohydrates, carotenoids, phenolics compounds, minerals, and vitamins. Besides the nutritional value, the food industry interest resides in the microalgae capability to be an alternative material, non-climate-dependent that grow on non-arable and non-productive land and do not compete with food production sites (CHAN et al., 2013; WAGHMARE et al., 2016). These microorganisms, as compared with other traditional plant sources, exhibit greater efficiency in the conversion of solar energy to biomass, which results in high growth rates (10 to 50 times faster than plants) (CHEN et al., 2016; WAGHMARE et al., 2016).

The use of microalgae-derived products has grown exponentially in recent decades, and microalgaederived food and nutraceutical products have enormous potential to slow the rate of malnutrition in developing nations. At the global level, the need for the development of clean, sustainable, and organic technologies to obtain food products, such as nutrients and natural bioactive compounds, demands a continuous search for species and/or varieties capable of synthesizing large amounts of specific compounds. The abundance of proteins and other essential nutrients in microalgae can be an alternative for the high production of healthy and functional foods (KRISHNA KOYANDE et al., 2019; MAADANE et al., 2015).

The genus Scenedesmus spp., and species Scenedesmus obliquus has been recently researched because containing various valuable bio-compounds and it is a very robust species, resistant to different $\mathrm{pHs}$ and climatic variations (SILVA et al., 2020). It is possible to be used in large scale and several places of the world, furthermore, exhibits a high growth rate (presenting great potential for exploitation) and is rich in lutein - a carotenoid of high biological value (CHNG; $\mathrm{CHAN}$; LEE, 2015; PŘIBYL et al., 2015). Some authors extracted carotenoids from Scenedesmus spp. and stated that the ease of cultivation and robustness of some strains of Scenedesmus makes them more suitable for sustainable large-scale production, being prone to the production of carotenoids and other compounds (PǨIBYL et al., 2015).

Research for the discovery of new pigments, their quantification, and verification of properties, covers both the medical and industrial area, due to their biological actions. In particular, the food sector is one of the most attracted by the challenge of searching natural and functional, in order to replace synthetic components to formulate food products (MAADANE et al., 2015; SATHASIVAM et al., 2019).
There is a wide range of compounds that could potentially be used as antioxidant agents, such as pigments including carotenoids, phenolic compounds, sulfated polysaccharides and long-chain polyunsaturated fatty acids (HAJIMAHMOODI et al., 2010; KIM et al., 2014; SINGH et al., 2015). There is a growing interest in finding new, powerful, and safe antioxidants from natural sources, to minimize oxidative injury to living cells and prevent oxidation in food, pharmaceutical or cosmetic products (HAJIMAHMOODI et al., 2010; MAADANE et al., 2015). Microalgae can provide solutions for these questions. Therefore, the objectives of this work were the $(i)$ extraction and characterization of fatty acids of $S$. obliquus and (ii) extraction, quantification, and evaluation of the antioxidant capacity of carotenoids and phenolic compounds of the studied microalga.

\section{MATERIAL AND METHODS}

The microalga Scenedesmus obliquus was cultivated in a raceway tank (capacity of $4.000 \mathrm{~L}$ of cultivation; $d=0.5 \mathrm{~g} \cdot \mathrm{L}^{-1}$ ), with sunlight incidence and in semi-discontinuous mode, in a medium rich in potassium chloride $\left(173.9 \mathrm{mg} \cdot \mathrm{L}^{-1}\right)$ and Urea $\left(180.0 \mathrm{mg} \cdot \mathrm{L}^{-1}\right)$ at the Biofuels Laboratory, Federal University of Viçosa, Viçosa, BR. The microalga growth curve was determined by optical density using absorbance of $650 \mathrm{~nm}$, and the biomass was collected by flocculation in the stationary growth phase (12 days). Cells were washed with distilled water and concentrated using a centrifuge $(3400 \cdot \mathrm{g}, 5 \mathrm{~min}$, Thermo Scientific, Heraeus multifuge X3R, USA) until the solid content reached approximately 10 to $15 \%$ (w/w).

In order to release the biological compounds from the microalga cells, cell disruption is required. The rupture was tested with a tip ultrasound (Sonics, VCX 750, USA) under the following conditions: frequency $=20 \mathrm{kHz}$; amplitudes $=60 ; 75$; or $90 \%$; times $=1 ; 3$; or 5 min; under ice bath to avoid the samples to be overheated. No longer times were tested to prevent overheating of the samples and consequent degradation of the compounds of interest.

For the quantification of ruptured and unruptured cells, cell counting was performed after staining with erythrosine $\mathrm{B}$ (1 $\left.\mathrm{mg} \mathrm{mL} \mathrm{mL}^{-1}\right)$ using a light microscope, following the methodology described by Gminski et al. (2011). In this assay, membranes from ruptured cells are permeable to the dye, while the unruptured cells remain uncolored. Besides, erythrosine B penetrates cells that have suffered critical damage to their plasma membranes. The breaking capacity is expressed as the percentage of broken cells compared to the total number of cells. From the results, the best disruption was chosen for further extraction of the compounds of interest. Upon choosing the best cell 
disruption (20 $\mathrm{kHz}$ frequency, 90\% amplitude, $5 \mathrm{~min}$ ), the biomass was frozen at $-40{ }^{\circ} \mathrm{C}$, freeze-dried, and stored in sterilized containers. The chemical composition of the dry microalgal biomass was characterized in terms of its content of moisture (AOAC 925.09, 2005), ashes (AOAC 923.03, 2005), lipids (AOAC 920.85, 2005), and protein (AOAC $920.87,2005)$. For the protein estimation, a conversion factor of $\mathrm{N}=5.89$ was used (AFIFY et al., 2018). The carbohydrate content was obtained by difference (ASSOCIATION OF OFFICIAL ANALYTICAL CHEMISTS, 2005).

The microalgal oil was converted to fatty acid methyl esters (FAMEs) to obtain the fatty acid profile of Scenedesmus obliquus, according to Ichihara and Fukubayashi (ICHIHARA; FUKUBAYASHI, 2010). Samples of the microalga oil were diluted in chloroform: methanol solution $(2: 1)$ and the lipids were transesterified with the addition of $8 \mathrm{M} \mathrm{HCl}$ solution in methanol, followed by incubation at $100{ }^{\circ} \mathrm{C}$ for $1 \mathrm{~h}$. The FAMEs were extracted using hexane, which was collected from the upper phase after centrifugation. The supernatant (solvent phase) was injected into a gas chromatograph equipped with a Flame Ionization Detector (GC-FID) (Shimadzu, GC-2010, Japan) and a capillary column of $100 \mathrm{~m}$ x $0.25 \mathrm{~mm}$ (SP-2560, Sigma-Aldrich, USA). The analysis was performed by direct injection of $1 \mu \mathrm{L}$ of the sample. Helium gas was used as the dragging gas and maintained at a constant flow rate of $363 \mathrm{kPa}$. The FAMEs were separated using a linear heating ramp from $60^{\circ} \mathrm{C}$ to $330^{\circ} \mathrm{C}$, at a heating rate of $20^{\circ} \mathrm{C} \mathrm{min}^{-1}$, and high linear velocity for better peak resolution. Peak identification was confirmed by comparison with the standard FAME mix (SupelCo 37 FAME mix, Sigma-Aldrich, USA).

The extraction of carotenoids was based on the methodology proposed by Howe and Tanumihardjo (2006). Carotenoids extraction was carried out using two organic solvents (petroleum ether or hexane) in order to evaluate the extraction yield. The extraction was started by adding pure acetone in the proportion of $6 \mathrm{~mL}$ for each $100 \mathrm{mg}$ of microalga. After 2 hours, the sample was centrifuged for 10 minutes at $7100 \cdot \mathrm{g}$. The procedure was repeated with acetone for $15 \mathrm{~min}$, washing until a clarified extract was obtained. From the extract obtained with acetone, extraction with the organic solvent in the ratio of 2:3 (organic solvent: acetone) was started. Deionized water was added, and the aqueous phase separated from the organic phase.

The organic phase, containing the carotenoids and interferents, such as chlorophyll and lipids, was saponified with a solution of $10 \% \mathrm{w} / \mathrm{v} \mathrm{KOH}$ in ethanol (SOARES et al., 2016). After $12 \mathrm{~h}$, the solution was washed with deionized water until complete separation in two phases: the greenish aqueous phase, and the yellow organic phase, in which the carotenoids would be contained. Absorbances were measured in a UV-Vis spectrophotometer (Cary 50), $350 \mathrm{~nm}$ at $700 \mathrm{~nm}$, and, thus, the amount of carotenoids was quantified according to Equation 1.

$$
C a\left(m g 100 g^{-1}\right)=\frac{A b s \times x 10^{4} \times D}{A x m} \quad \text { Equation } 1
$$

in which, $\mathrm{Ca}$ is carotenoids, Abs is the absorbance of the sample at the wavelength corresponding to carotenoids; ' $\mathrm{V}$ ' is the volume of the sample; ' $\mathrm{D}$ ' is the dilution factor; ' $A$ ' is the extinction coefficient, and ' $\mathrm{m}$ ' is the initial mass of the microalga.

Phenolic compounds extraction was performed based on the methodology proposed by Singleton and Rossi (SINGLETON; ROSSI, 1965), with some modifications. Ethanol was utilized as the extraction solvent, in which the mixture was left under stirring for $3 \mathrm{~h}$. Subsequently, a filtration step was carried out, followed by 2 washes with ethanol, obtaining a solution containing the compounds of interest.

In order to quantify the amount of phenolic compounds, $0.4 \mathrm{~mL}$ of extract was mixed with $2.1 \mathrm{~mL}$ of deionized water, $2.0 \mathrm{~mL}$ of $2.0 \%$ sodium carbonate $\left(\mathrm{Na}_{2} \mathrm{CO}_{3}\right)$ and $0.5 \mathrm{~mL}$ of Folin-Ciocalteau reagent, adjusting the final volume to $10 \mathrm{~mL}$. The analytical curve of gallic acid with 10 points, was prepared by using $2.4 \mathrm{~mL}$ of deionized water, maintaining the remaining proportions of the reagents. Then the blends were allowed to stand for $60 \mathrm{~min}$ at room temperature so that the absorbances were measured on a UV-Vis spectrophotometer (Cary 50) at $750 \mathrm{~nm}$ using deionized water as blank.

The total concentration of phenolic compounds in the extract was determined from linear regression with the analytical curve of gallic acid (AGE), varying the concentration between 0 and $1000 \mathrm{mg} \mathrm{mL}^{-1}$ of gallic acid, with the results expressed in $\mathrm{mg}$ of $\mathrm{AGE} \cdot \mathrm{mL}^{-1}$ of extract and $\mathrm{mg}$ of phenolic compounds $100 \mathrm{~g}^{-1}$ of microalga. A standard curve of gallic acid (AGE) was made to find the concentration of the total phenolics.

The method used to evaluate the antioxidant activity is based on the reduction of 2,2-diphenyl-1picrylhydrazyl, DPPH, by the action of an antioxidant or a radical species, to form diphenyl-picrylhydrazine, which presents a yellowish color. The results were obtained by monitoring the decrease in the absorbance values.

The percent inhibition of DPPH was obtained by modifying the method of Brand-Williams, Cuvelier and Berset (1995). Briefly, a solution of $60 \mu \mathrm{mol} \cdot \mathrm{L}^{-1} \mathrm{DPPH}$ in methanol was prepared. Then, aliquots of $2.9 \mathrm{~mL}$ were withdrawn from the resulting solution and mixed with $100 \mu \mathrm{L}$ of the phenolic compounds extract (CF) (411.69 $\mu \mathrm{g} \mathrm{AGE} \cdot \mathrm{mL}^{-1}$ extract), and methanol as control. The same procedure was performed for carotenoids extracts (195.79 $\mu \mathrm{g} \cdot \mathrm{mL}^{-1}$ in hexane $-\mathrm{CHX}$, and $184.71 \mu \mathrm{g} \cdot \mathrm{mL}^{-1}$ in petroleum 
ether-CEP, respectively). After stirring, the mixture was left in the dark at room temperature for $90 \mathrm{~min}$.

Then, the absorbance of the samples was read, every $30 \mathrm{~min}$ of reaction, in a spectrophotometer at $517 \mathrm{~nm}$, in order to obtain the percentage of inhibition, expressed by Equation 2.

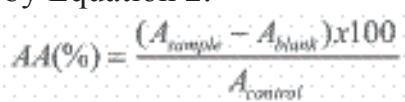

Equation 2

in which, $\mathrm{A}_{\text {control }}$ is the absorbance of the DPPH solution with methanol as the control, $A_{\text {sample }}$ is the absorbance of the DPPH solution with the test sample and $\mathrm{A}_{\text {blank }}$ is the absorbance of the sample without the DPPH solution.

\section{RESULT AND DISCUSSION}

The ability of cells to rupture, using ultrasound as a mechanical disruption method, can be seen in figure 1 . The ratio of ruptured cell augmentation was directly proportional to the increase in equipment amplitude and time. Therefore, the capacity of cellular rupture and consequent extravasation of the cellular material is directly related to the amplitude of the equipment and time of treatment undergone.

With the maximum amplitude (90\%) and longer time ( $5 \mathrm{~min}$ ) tested a breakability of the cells of approximately $95 \%$ was observed, and this treatment was chosen for later application and extraction of compounds.

Singh et al. (2015), verified the extraction of carotenoids with and without cell disruption and concluded that acetone is unable to extract all intracellular carotenoids without effective cell disruption. From the moment, the cell wall was disrupted by ultrasound, the

Figure 1 - Percentage of ruptured cells of microalga Scenedesmus obliquus using ultrasound, with an amplitude of 60,75 , or $90 \%$, at times of $1 ; 3$ or $5 \mathrm{~min}$

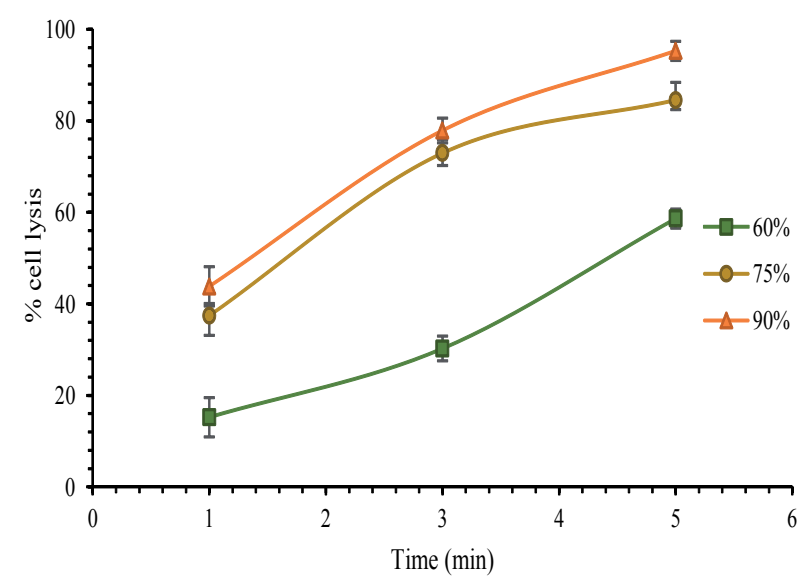

astaxanthin yield was exponential, and this was directly related to the percentage of ruptured cells.

The results of the centesimal composition of $S$. obliquus microalgal biomass are presented in Table 1 . As can be seen, the microalga presents high amounts of compounds that are considered of great interest in the food industry, such as high protein, lipid, and carbohydrate contents. Protein values of 40.42 and $40.69 \%$ were found by Silva et al. (2020), Afify et al. (2018), respectively, for microalga Scenedesmus obliquus. Silva et al. (2020), found values of $05.57 \%$ for lipids, $28.0 \%$ for carbohydrates, and $15.64 \%$ for ash. The values of the centesimal composition of microalgae vary within the same species according to the type of cultivation used, collection time, and stress factors, such for example, as absence or excess of nutrients (AFIFY et al., 2018;; ROCHA et al., 2019; SILVA et al., 2020; SOARES et al., 2018).

The fatty acid profile of the microalga Scenedesmus obliquus, presented in Figure 2, indicates the predominance of unsaturated and polyunsaturated fatty acids.

Regarding the saturated fatty acid methyl ester (FAME), palmitic acid (C16: 0) accounts for 29\% of total fatty acids. The fatty acid profile of the microalga Scenedesmus obliquus, presented in Figure 2, indicates the predominance of unsaturated and polyunsaturated fatty acids. Regarding the saturated fatty acid methyl ester (FAME), palmitic acid (C16: 0) accounts for 29\% of total fatty acids. On the other hand, for unsaturated fatty acids, the amount of polyunsaturated fatty acids (PUFA's) corresponds to $47.31 \%$ of the total, with predominance of omega-3 (n-3 PUFA), linolenic acid (16.74\%), and approximately $9.70 \%$ of omega- 6 , with the presence of linoleic acid (n-6 PUFA) and linolelaidic acid. This high amount of linolenic acid (n-3), an essential fatty acid of the omega-3 family present in microalga $S$. obliquus, suggests the use of this species as a source of such fatty acid, which can be extracted and used to supplement food and increase consumption for the population. In addition, S. obliquus also has linoleic acid (n-6), which is an essential fatty acid of the omega-6 family, in a significant amount (4.79\%).

Table 1 - Centesimal composition of microalga Scenedesmus obliquus

\begin{tabular}{lc}
\hline Components & $\left(\% \mathrm{~g} .100 \mathrm{~g}^{-1}\right)$ \\
\hline Moisture & 8.03 \\
Protein $($ factor $=5.89)$ & 37.15 \\
Lipids & 10.29 \\
Ashes & 20.24 \\
Carbohydrates & 21.93 \\
\hline
\end{tabular}


Figure 2 - Fatty acid composition of microalga Scenedesmus obliquus oil

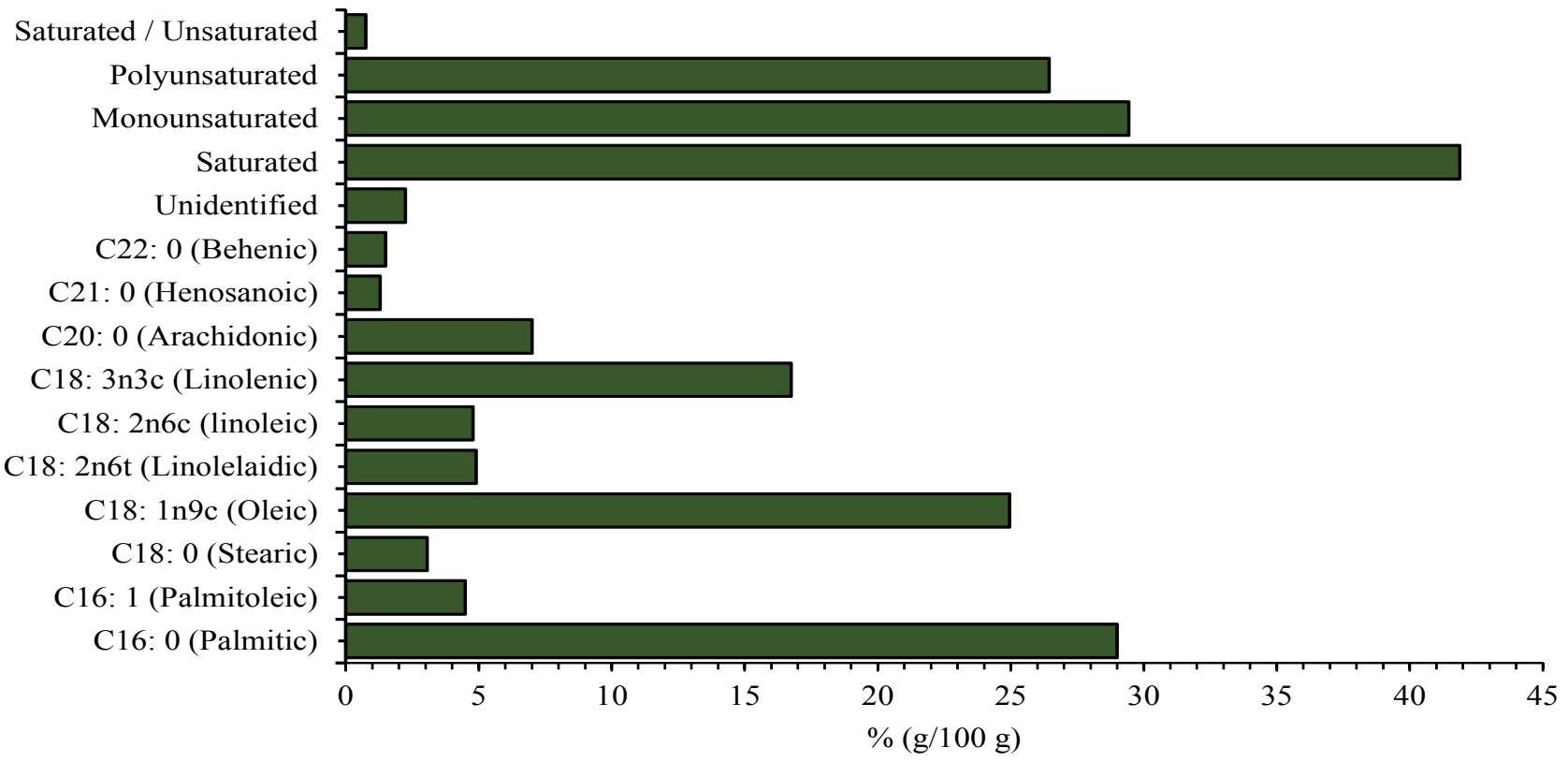

The results found in the present study from the fatty acid profile of microalga $S$. Obliquus, are in agreement with results found by other authors (ROCHA et al., 2019; SILVA et al., 2020; WILTSHIRE et al., 2000). Silva et al. (2020) found significant amounts of C18:3n3, C18:2n6, and C18:1n9 in oil extracted from the microalgae $S$. obliquus, stating that this microalga has the potential to be sources of these compounds. Rocha et al. (2019), found high amounts of linolenic $(>15 \%)$, oleic $(>14 \%)$, and linoleic acids ( $>10 \%$ ) for the different types of crops tested by these authors and demonstrate, in their work, that the type of cultivation significantly affects the fatty acid profile of the microalgae S. obliquus oil.

The benefits of omega-3 polyunsaturated fatty acids consumption for health are already well known, and their influence on brain development and prevention of cardiovascular diseases has been proven in different epidemiological and clinical studies (CALDER, 2014; GHEYSEN et al., 2018). Besides, consumption of n-3 PUFA is lower than that of n-6 PUFA, so the incentive for the consumption of $n-3$ PUFA is high, and there is a growing interest in enriching food products with n-3 PUFA. It should be noted that the ingestion of such products is still far below that recommended, in several countries (RYCKEBOSCH et al., 2012; SIOEN et al., 2010). Several authors report some species of microalgae as a sustainable alternative source of polyunsaturated fatty acids of the omega 3 family. The use of those microalgae species could be a way to increase the consumption of n-3 PUFA, given the reduction of the world stocks of fish and fish oils (GHEYSEN et al., 2018; RYCKEBOSCH et al., 2012; SATHASIVAM et al., 2019; SILVA et al., 2020). The omega-3 lipid accumulation in the microalgae Dunaliella salina and Chlorella vulgaris was induced and stimulated by the use of saline stress (RISMANI; SHARIATI, 2017).

The levels of total carotenoids extracted from S. obliquus were $1.61 \pm 0.18$ and $1.03 \pm 0.03 \mathrm{~g} \cdot 100 \mathrm{~g}^{-1}$ microalga, respectively for hexane and petroleum ether, with hexane being the most efficient solvent for this extraction compared to petroleum ether.

Most carotenoids have therapeutic value, being effective agents for preventing a variety of human diseases, including anti-cancerous and anti-inflammatory activities, due to its strong antioxidant effect which is used to protect against oxidative stress. The natural form of these compounds has a stronger effect and can be easily absorbed by the body when compared to the synthetic form. Therefore, the high consumption of natural carotenoids and the research of new sources and ways to increase the production of these bioactive compounds has been widely encouraged (CHEN et al., 2016). Furthermore, several authors reported the high accumulation of lutein as the major carotenoid of the microalgae of the genus Scenedesmus spp. (CHAN et al., 2013; PŘIBYL et al., 2015).

According to Pribyl et al. (2015), on their study with the microalgae Scenedesmus sp. in a 7-day culture in the laboratory, these microalgae presented a content of $0.68 \%$ carotenoids, while in a 14 -day culture with saline stress, it reached $2.08 \%$ of carotenoids, indicating that the 
culture time and the induced stress influenced the amount of accumulated carotenoids. Besides, these authors reported that thermotolerance is a common feature in Scenedesmus spp., which makes this microalgae genus more interesting for future large-scale production of biomass rich in carotenoids.

Several studies have been reported about the influence of stresses on microalgae for carotenoid accumulation. Some studies have shown that the production of $\beta$-carotene can be increased by intervention in the growing conditions. For instance, high salinity, reduced nutrient content, high light incidence, and extreme temperature are extrinsic parameters that could be controlled in order to increase the carotenoid contents in Scenedesmus spp. (KRISHNA KOYANDE et al., 2019; RAJA et al., 2007). In addition, an increase in lutein and astaxanthin has also been reported with induced stress in the culture (CHAN et al., 2013; HIGUERA-CIAPARA; FÉLIX-VALENZUELA; GOYCOOLEA, 2006).

In some species of microalgae, the synthesis of lipids and pigments occurs in a coordinated manner. Thus, in adverse conditions, lipids are produced in response to stress and accumulate in cytoplasmic oily bodies. In these places, some carotenoids are also deposited and can exert antioxidant activity in protecting unsaturated lipids against peroxidation (KIM et al., 2014). In this way, the accumulation of these compounds of interest can be induced even without affecting its quality.

The microalga $S$. obliquus presented high amount of carotenoids and high extraction capacity of such bioactive compounds by using organic solvent and thus considered as a source of natural carotenoids. However, this amount can still be improved through the induction of stress in microalga cultivation.

The results obtained for the extraction of phenolic compounds was $411.69 \mu \mathrm{g} \mathrm{AGE} \cdot \mathrm{mL}^{-1}$ in the extract. The microalga $S$. obliquus presented $1.12 \mathrm{~g}$ of total phenolic compounds in $100 \mathrm{~g}$ of microalga. Similar results were found by Silva et al. (2020). The microalga Arthrospira platensis, mutants were induced by an electron beam, and the total phenolics increased from $9.7 \mathrm{mg} \mathrm{L}^{-1}$ to $17.0 \mathrm{mg} \mathrm{L}^{-1}$ and consequently increased antioxidant activity (KIM et al., 2014).

The microalgae react in different ways in the defenses against free radicals and oxidations, including reactive enzymes in the elimination of oxygen and antioxidant activity. Antioxidant agents, such as phenolic compounds, acted as free radical oxidation terminators and were recognized for their physiological, biological and medicinal activity, receiving increasing attention in the areas of health, biology, and food, especially in the search for natural antioxidants that can prevent degenerative diseases (KIM et al., 2014; ROJAS; BUITRAGO, 2019).
Studies evaluating the in vivo activity of phenolic compounds have found several beneficial actions in these extracts, including anti-prostate cancer agents, plasma antioxidant, with a beneficial to oxidative damage, and activity antioxidants for the prevention of degenerative diseases (HAJIMAHMOODI et al., 2010; KAZUI et al., 2018).

The results of the antioxidant activity of carotenoid extracts and phenolic compounds of the microalga Scenedesmus obliquus were obtained using the DPPH method (Figure 3).

Carotenoid extracts and phenolic compounds showed a high percentage of inhibition of oxidation $>88 \%$ and $>72 \%$, respectively) at all times analyzed $(30,60,90 \mathrm{~min})$ (Figure 3). The higher the percentage of inhibition, the higher the DPPH consumption by the sample, and the higher the antioxidant activity (MAADANE et al., 2015). In this way, it is noticeable that the carotenoids and phenolic compounds extracted from the microalga Scenedesmus obliquus presented antioxidant activity with up to $95 \%$ inhibition even when using low concentrations. Silva et al. (2020), found a percentage of inhibition of DPPH oxidation of $95.53 \%$ for carotenoid extracts and $96.09 \%$ for phenolic compounds extracted from the microalga $S$. obliquus. Other species reported in the literature also showed antioxidant potential, such as the study by Maadane et al. (2015), in which they found high antioxidant potential in several strains of microalgae, with greater DPPH inhibition capacity $(>80 \%)$ Dunalliela $\mathrm{sp}$. Tetraselmis sp. and Nannochloropsis gaditana. These microalgae had a high content of total polyphenols,

Figure 3 - Evaluation of the antioxidant activity of the carotenoids extracts $\left(195.79 \mu \mathrm{g} \cdot \mathrm{mL}^{-1}\right.$ in hexane - CHX, and $184.71 \mu \mathrm{g} \cdot \mathrm{mL}^{-1}$ petroleum ether - CEP) and phenolic compounds $(411.69 \mu \mathrm{g}$ AGE $\cdot \mathrm{mL}^{-1}$ extract) of the microalga Scenedesmus obliquus

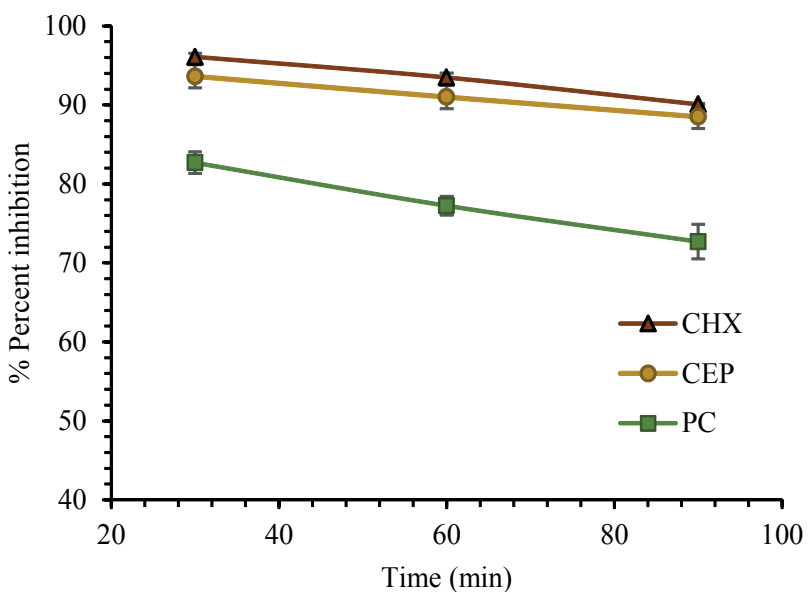


carotenoids and PUFA, indicating that these strains may be a potential new source of natural antioxidants.

The experiment was conducted by measuring the absorbance of the samples every 30 min., during 90 min. The decrease in the percentage of inhibition was observed over time. This reduction in antioxidant activity is associated with the oxidation process of carotenoids during the reaction with the free radicals (FR) generated by DPPH. The antioxidant activity of phenolic compounds is mostly due to their oxi-reduction properties, which may play a role in the absorption and neutralization of free radicals (MAADANE et al., 2015).

The microalga S. obliquus presented a high amount of carotenoids, phenolic compounds, and antioxidant activity even in low concentrations, in relation to other species reported in the literature (HAJIMAHMOODI et al., 2010; MAADANE et al., 2015; RISMANI; SHARIATI, 2017) demonstrating a potential use in the food industry. According to Devi et al. (2009), the food industry is seeking the use of natural antioxidants, isolated from plants and seaweed, to replace synthetic food additives, since these non-natural additives may have harmful effects on health. Also, the oxidative stress that is involved in the development of various degenerative diseases attracted the interest of researchers in investigating the antioxidant activity of natural products. The consumption of phenolic compounds can help the human body to reduce the damage oxidative diseases related to aging and diseases such as arteriosclerosis, ulcer, diabetes, and cancer (DEVI et al., 2009; KAZUI et al., 2018).

In a study carried out by Silva et al. (2020), it was verified the consumption of microalga $S$. obliquus by Wistar rats and observed that the amounts of bioactive compacts of this microalgae, including carotenoids, phenolic compounds, essential fatty acids, etc., significantly affected the content of triglycerides (70\%), the atherogenic index (80\%) and the concentration of serum glucose $(42 \%)$, in the blood of the animals, even using a balanced diet. In addition, these authors reported that $S$. obliquus may represent a promising sustainable source of functional and nutraceutical foods for possible prevention and treatment of diabetes and dyslipidemia.

\section{CONCLUSIONS}

1. The microalga $S$. obliquus showed a high concentration of polyunsaturated fatty acids including alpha-linolenic acid, from the omega-3 family. In addition, significant amounts of carotenoids and phenolic compounds were extracted from $S$. obliquus, and showed antioxidant activity with a percentage of inhibition of up to $95 \%$, even using low concentrations;

2. Thus, it is concluded that the microalga Scenedesmus obliquus is an alternative, natural and sustainable source of biologically active compounds, which can potentially be used in supplementation or as an additive in the food and pharmaceutical industries.

\section{ACKNOWLEDGMENTS}

The authors are grateful the financial support of the Conselho Nacional de Desenvolvimento Científico e Tecnológico (CNPq), FAPEMIG, and Coordenação de Aperfeiçoamento de Pessoal de Nível Superior (CAPES) Brazilian agencies and the PETROBRAS.

\section{REFERENCES}

AFIFY, A. E. M. M. R. et al. Scenedesmus obliquus: antioxidant and antiviral activity of proteins hydrolyzed by three enzymes. Journal of Genetic Engineering and Biotechnology, 2018.

ASSOCIATION OF OFFICIAL ANALYTICAL CHEMISTS. Official methods of analysis. 18 th ed. Washington, D. C.: Association of Official Agricultural Chemists, 2005.

BRAND-WILLIAMS, W.; CUVELIER, M. E.; BERSET, C. Use of a free radical method to evaluate antioxidant activity. LWT Food Science and Technology, v. 28, n. 1, p. 25-30, 1995.

CALDER, P. C. Very long chain omega-3 (n-3) fatty acids and human health. European Journal of Lipid Science and Technology, v. 116, n. 10, p. 1280-1300, 2014.

CHAN, M. et al. Characterization, extraction and purification of lutein produced by an indigenous microalga Scenedesmus obliquus CNW-N. Biochemical Engineering Journal, v. 78, p. 24-31, 2013.

CHEN, J. et al. Microalgal industry in China: challenges and prospects. Journal of Applied Phycology, v. 28, n. 2, p. 715 $725,2016$.

CHNG, L. M.; CHAN, D. J. C.; LEE, K. T. Sustainable production of bioethanol using lipid-extracted biomass from Scenedesmus dimorphus. Journal of Cleaner Production, v. 130, p. $68-73,2015$.

DEVI, M. K. A. et al. Functional attributes of soybean seeds and products, with reference to isoflavone content and antioxidant activity. Food Chemistry, v. 114, n. 3, p. 771-776, 1 jun. 2009.

GHEYSEN, L. et al. Impact of processing on n-3 LC-PUFA in model systems enriched with microalgae. Food Chemistry, v. 268, p. 441-450, 1 dez. 2018.

GMINSKI, R. et al. Genotoxic effects of three selected black toner powders and their dimethyl sulfoxide extracts in cultured human epithelial A549 lung cells in vitro. Environmental and Molecular Mutagenesis, v. 52, n. 4, p. 296-309, 2011. 
HAJIMAHMOODI, M. et al. Evaluation of antioxidant properties and total phenolic contents of some strains of microalgae. Journal of Applied Phycology, v. 22, n. 1, p. 43-50, 2010.

HIGUERA-CIAPARA， I.; FÉLIX-VALENZUELA， L.; GOYCOOLEA, F. M. Astaxanthin: a review of its chemistry and applications. Critical Reviews in Food Science and Nutrition, v. 46 , n. 2, p. 185-196, mar. 2006.

HOWE, J.; TANUMIHARDJO, S. Evaluation of analytical methods for carotenoid extraction from biofortified maize (Zea mays sp.). Journal of Agricultural and Food Chemistry, v. 54, n. 21, p. 7992-7997, 22 set. 2006.

ICHIHARA, K.; FUKUBAYASHI, Y. Preparation of fatty acid methyl esters for gas-liquid chromatography. Journal of Lipid Research, v. 51, n. 3, p. 635-640, 2010.

KAZUI, Y. et al. Structure-activity relationship of novel (benzoylaminophenoxy)phenol derivatives as anti-prostate cancer agents. Bioorganic \& Medicinal Chemistry, v. 26, n. 18 , p. $5118-5127,1$ out. 2018.

KIM, Y.-H. et al. Electron beam-induced mutants of microalgae Arthrospira platensis increased antioxidant activity. Journal of Industrial and Engineering Chemistry, v. 20, n. 4, p. 1834-1840, 25 jul. 2014.

KRISHNA KOYANDE, A. et al. Microalgae: a potential alternative to health supplementation for humans. Food Science and Human Wellness, 2019.

MAADANE, A. et al. Antioxidant activity of some moroccan marine microalgae: Pufa profiles, carotenoids and phenolic content. Journal of Biotechnology, v. 215, p. 13-19, 2015.

PŘIBYL, P. et al. Elevated production of carotenoids by a new isolate of Scenedesmus sp. Algal Research, v. 11, p. 22-27, 2015.

RAJA, R. et al. Protective effect of Dunaliella salina (Volvocales, Chlorophyta) against experimentally induced fibrosarcoma on wistar rats. Microbiological Research, v. 162, n. 2, p. 177-184, 10 abr. 2007.

RISMANI, S.; SHARIATI, M. Changes of the total lipid and omega-3 fatty acid contents in two microalgae Dunaliella salina and Chlorella ulgaris under salt stress. Brazilian Archives of Biology and Technology, v. 60, p. 1-11, December, 2017.

ROCHA, D. N. et al. Combination of trace elements and salt stress in different cultivation modes improves the lipid productivity of Scenedesmus spp. Bioresource Technology, v. 289 , p. 121644,1 out. 2019.

ROJAS, J.; BUITRAGO, A. Antioxidant activity of phenolic compounds biosynthesized by plants and Its relationship with prevention of neurodegenerative diseases. [S. l.]: Elsevier, 2019.

RYCKEBOSCH, E. et al. Microalgae as an alternative source of omega-3 long chain polyunsaturated fatty acids. Lipid Technology, v. 24, n. 6, p. 128-130, 2012.

SASSI, K. K. B. et al. Metabolites of interest for food technology produced by microalgae from the Northeast Brazil. Revista Ciencia Agronomica, v. 50, n. 1, p. 54-65, 2019.

SATHASIVAM, R. et al. Microalgae metabolites: a rich source for food and medicine. Saudi Journal of Biological Sciences, v. 26, n. 4, p. 709-722, 1 maio 2019.

SILVA, M. E. T. da et al. Food safety, hypolipidemic and hypoglycemic activities, and in vivo protein quality of microalga Scenedesmus obliquus in Wistar rats. Journal of Functional Foods, v. 65, p. 103711, 1 fev. 2020.

SINGH, D. et al. Understanding response surface optimisation to the modeling of Astaxanthin extraction from a novel strain Thraustochytrium sp. S7. Algal Research, v. 11, p. 113-120, 2015.

SINGLETON, V. L.; ROSSI, J. A. Colorimetry of total phenolics with phosphomolybdic-phosphotungstic acid reagents. American Journal of Enology and Viniculture, v. 16, p. 144-158, 1965.

SIOEN, I. et al. The influence of n-3 PUFA supplements and n-3 PUFA enriched foods on the n-3 LC PUFA intake of flemish women. Lipids, v. 45, n. 4, p. 313-320, 2010.

SOARES, A. T. et al. Improvement of the extraction process for high commercial value pigments from desmodesmus sp. microalgae. Journal of the Brazilian Chemical Society, v. 27, n. 6, p. 1083-1093, 2016.

SOARES, J. et al. Scenedesmus sp. cultivation using commercialgrade ammonium sources. Annals of Microbiology, v. 68, n. 1, p. 35-45, 2018.

WAGHMARE, A. G. et al. Concentration and characterization of microalgae proteins from Chlorella pyrenoidosa. Bioresources and Bioprocessing, 2016.

WILTSHIRE, K. H. et al. Extraction of pigments and fatty acids from the green alga Scenedesmus obliquus (Chlorophyceae). Aquatic Ecology, v. 34, n. 2, p. 119-126, 2000. 